\title{
Global and regional climate in 2007
}

\section{John Kennedy, Holly Titchner, David Parker, Mark Beswick, Jen Hardwick and Peter Thorne \\ Met Office, Hadley Centre, Exeter}

The global average near-surface temperature in 2007 was $0.40 \pm 0.10 \mathrm{deg} C$ above the 1961-1990 average (Figure 1(a)) and 2007 was nominally the seventh-warmest year in the 158-year HadCRUT3 record (Brohan et al., 2006). The year was characterized by a record-low Arctic sea-ice extent and by unusually high temperatures over the North Atlantic and much of Eurasia.

The HadCRUT3 dataset is calculated from land-surface air temperature measurements made at about 4350 land stations and a database of approximately 190 million sea-surface temperature (SST) observations collected since 1850. However, the global average temperature cannot be calculated exactly because large areas of the Earth's surface remain unobserved and measurements are prone to errors and biases. The uncertainties are such that none of the nine warmest years are distinguishable in a statistically meaningful way and therefore it is not possible to state with absolute certainty that 2007 was the seventh-warmest year on record. Nonetheless, it is virtually certain that 2007 was one of the ten warmest.

1998 remains the warmest year on record with a global average near-surface temperature anomaly of $0.52 \pm 0.10 \mathrm{deg} C$ above the 1961-1990 average (Figure 1(a)). The exceptional warmth of 1998 was a result of the strong El Niño that developed towards the end of 1997. A moderate El Niño developed towards the end of 2006 and in January 2007, which was the warmest January in the record, the Met Office Hadley Centre issued a forecast saying that there was a 60\% chance that 2007 would be warmer than 1998. But SSTs in the tropical Pacific fell rapidly, dropping below La Niña thresholds by May and, subsequently, global average
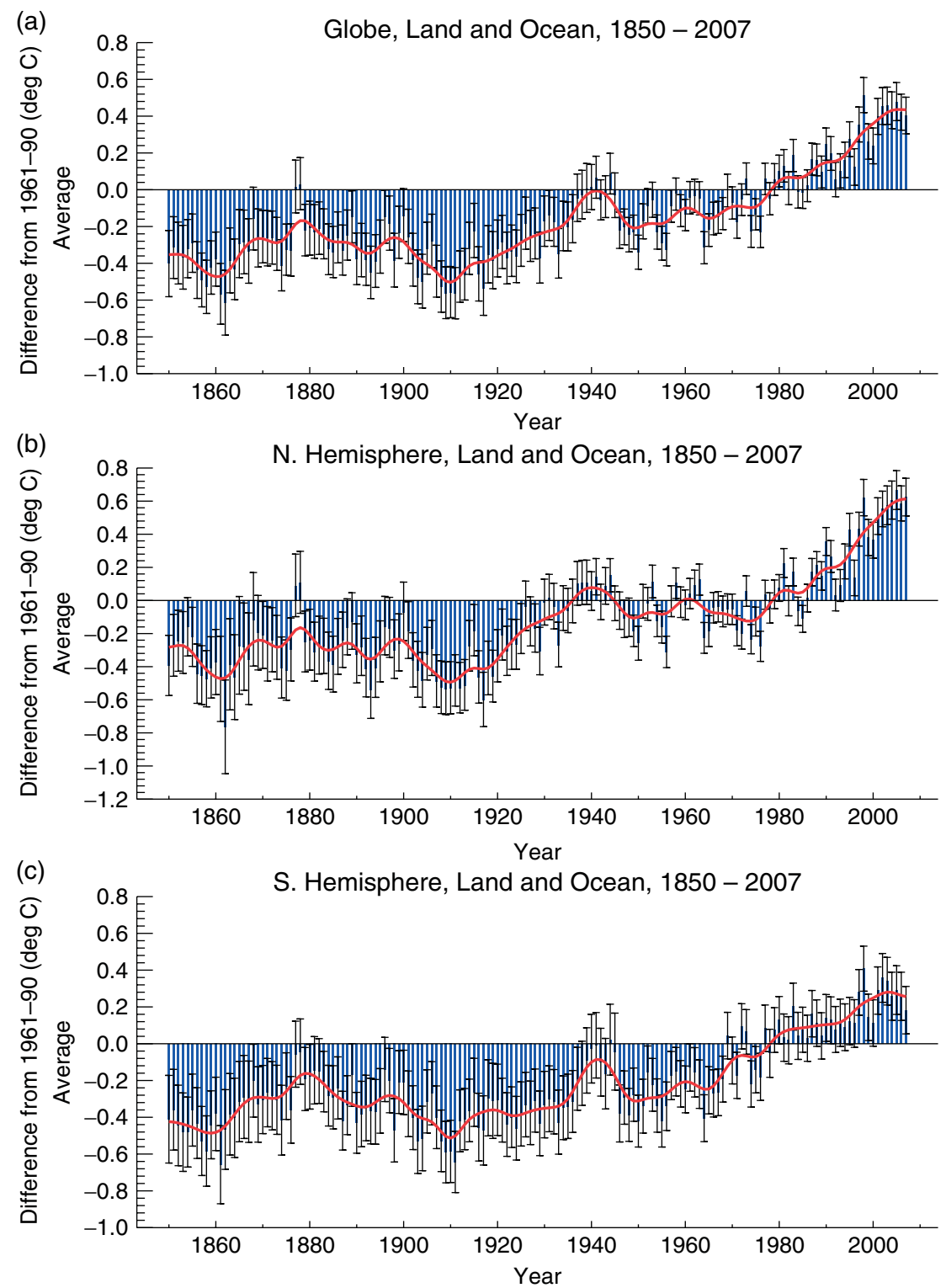

Figure 1. (a)-(c) Annual combined land-surface air and sea-surface temperature anomalies (degC) for the period 1850-2007, relative to the average for 1961-1990. (a) Globe; (b) Northern Hemisphere; (c) Southern Hemisphere. The uncertainty range represents \pm 2 standard errors. The smooth curves were created using a 21-point binomial filter to highlight the interdecadal variations. Data are from Brohan et al. (2006).

La Niña had become the strongest since that of 1988/1989 (Figure 2).

The annual average Northern Hemisphere $(\mathrm{NH})$ near-surface temperature anomaly in 2007 was $0.63 \pm 0.11 \mathrm{degC}$ (Figure $1(\mathrm{~b})$ ). It is virtually certain to be one of the eight warmest years on record. The Southern
Hemisphere (SH, Figure 1(c)) was somewhat cooler with an annual average anomaly of $0.18 \pm 0.13 \mathrm{deg} C$ and, given the uncertainties, it may have been the fourth-warmest or not even in the top twenty. The annual average temperature anomaly for the tropics $\left(20^{\circ} \mathrm{N}\right.$ $20^{\circ} \mathrm{S}$ ) was $0.30 \pm 0.03 \mathrm{deg} \mathrm{C}$, somewhere 

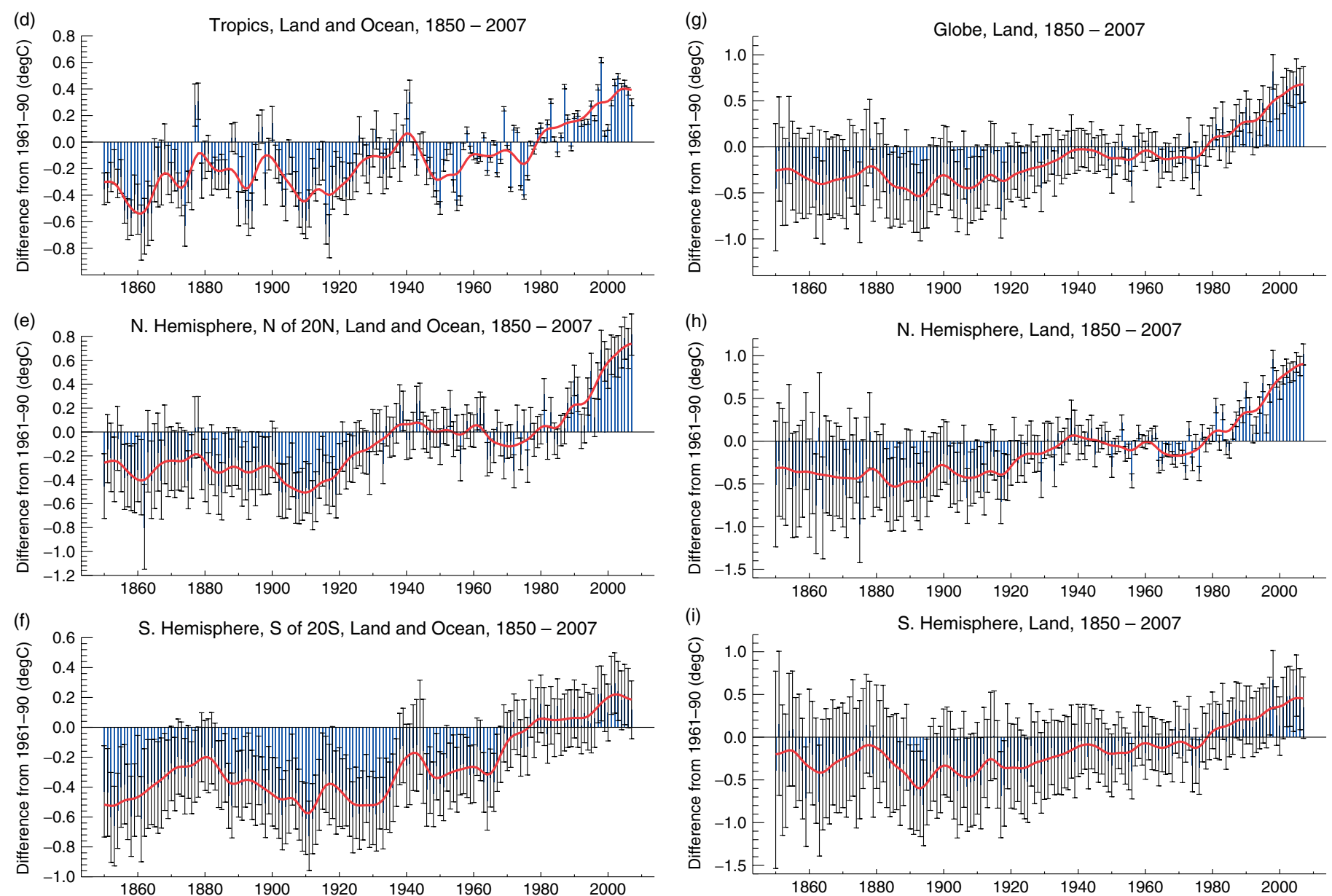

Figure 1. (d)-(f) Annual combined land-surface air and sea-surface temperature anomalies (degC) for the period 1850-2007, relative to the average for 1961-1990. (d) Tropics $20^{\circ} \mathrm{N}-20^{\circ} \mathrm{S}$; (e) Northern Hemisphere north of $20^{\circ} \mathrm{N}$; (f) Southern Hemisphere south of $20^{\circ} \mathrm{S}$. The uncertainty range represents \pm 2 standard errors. Data are from Brohan et al. (2006).

Figure 1. (g)-(i) Annual land-surface air temperature anomalies (degC, relative to the average for 1961-90) for the period 1850-2007. (g) Globe; (h) Northern Hemisphere; (i) Southern Hemisphere. The uncertainty range represents \pm 2 standard errors. The smooth curves were created using a 21 point binomial filter to highlight the interdecadal variations in the data. Data are from Brohan et al. (2006).

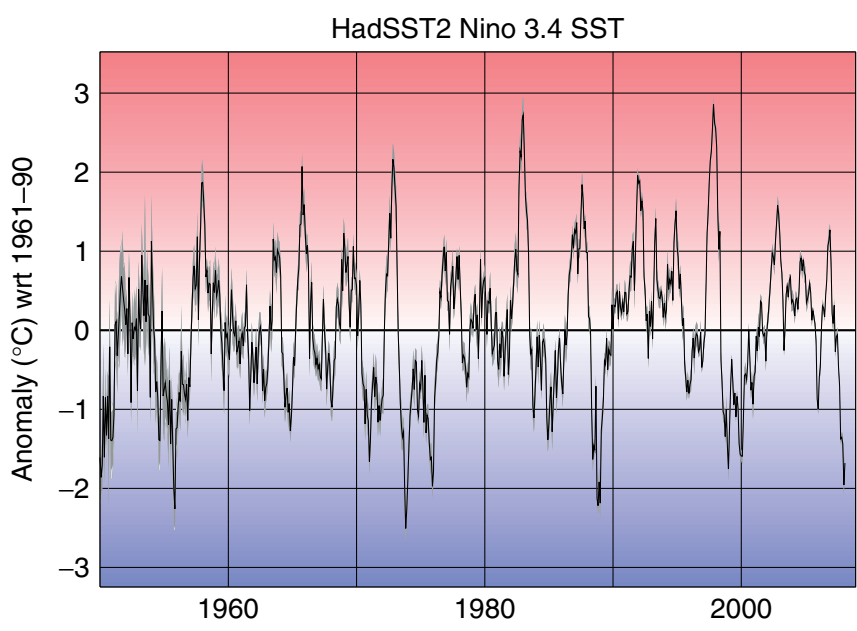

Figure 2. Monthly average sea-surface temperature anomalies relative to 1961-1990, January 1950 -February 2008, for the Nino 3.4 region of the Tropical Pacific $\left(170^{\circ} \mathrm{W}-120^{\circ} \mathrm{W}, 5^{\circ} \mathrm{S}-5^{\circ} \mathrm{N}\right)$. The black line shows the best estimate of the average SST and the narrow grey area indicates the 95\% confidence range of the uncertainty. Warm El Niño events in the eastern equatorial Pacific Ocean in 1982-1983, 1987, and 1997-1998 coincided with global warmth, but El Niño events are often followed by cooler La Niña events as in 1985, 1988, 1998-1999 and 2007. Data are from HadSST2 (Rayner et al. 2006).

between the tenth- and sixteenth-warmest on record. Uncertainties on tropical average temperatures are much lower than for other areas owing to the thermal homogeneity of the tropics (Figure 1(d)).
The global average land-surface air temperature in 2007 was $0.68 \pm 0.19 \mathrm{degC}$ above the long-term average (Figure 1(g)) and it was among the ten warmest years on record. The uncertainties on land-surface temperatures are larger than on combined land- and sea-surface temperatures because of the greater variability of air temperature over land. In 2007, the NH land-surface air temperature anomaly was $1.02 \pm 0.12 \mathrm{deg} C$ (among the three warmest, Figure 1(h)) but the $\mathrm{SH}$ land-surface air temperature anomaly, at $0.35 \pm 0.36 \mathrm{deg} C$, has only a $95 \%$ probability of being above the 1961-1990 average (Figure 1(i)).

Annual average near-surface temperatures in 2007 were above the 1961-1990 average over large areas (Figure 3(a)). Significant warm anomalies - temperatures exceeding the 90th percentile of occurrence (Horton et al., 2001, Figure 3(b)) - were observed over much of Asia, Europe, north-west Africa, the United States, Brazil, Australia and the Indian Ocean. Large areas of the North Atlantic were also significantly warmer than average, reflecting the continuing warm phase of the Atlantic Multi-decadal Oscillation (AMO, Knight et al., 2005), which began in the mid-90s. The AMO has been shown to influence north-eastern Brazilian and African Sahel rainfall, Atlantic hurricanes and North American and European summer climate (Knight et al., 2006). Arctic temperatures are not marked as being above the 


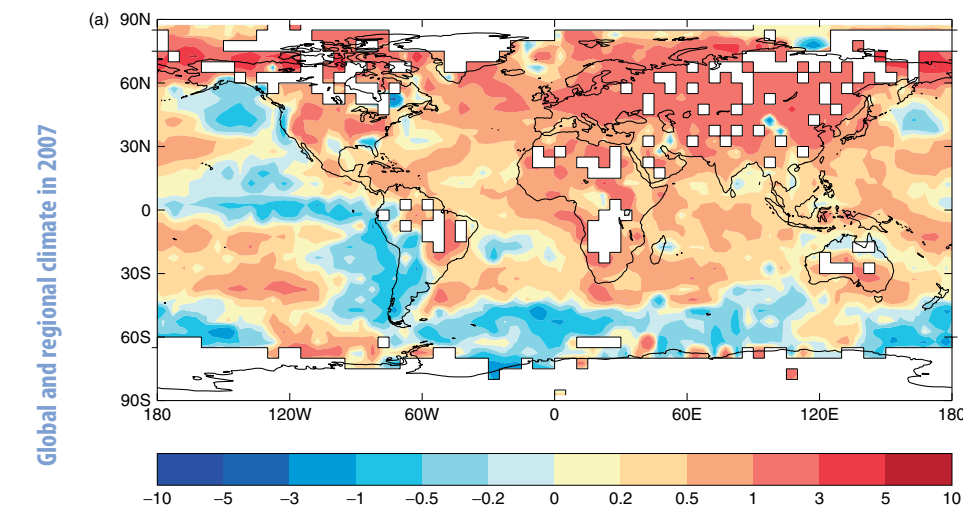

Figure 3(a). Land-surface air and sea-surface temperature anomalies 으 (degC, relative to 1961-1990) for 2007. The temperature value for each $5^{\circ}$ latitude $\times 5^{\circ}$ longitude pixel is derived by averaging at least 1 month's anomaly in each of four 3-month seasons (January to March, etc.) and then averaging the resulting seasonal anomalies. Data are from Brohan et al. (2006)

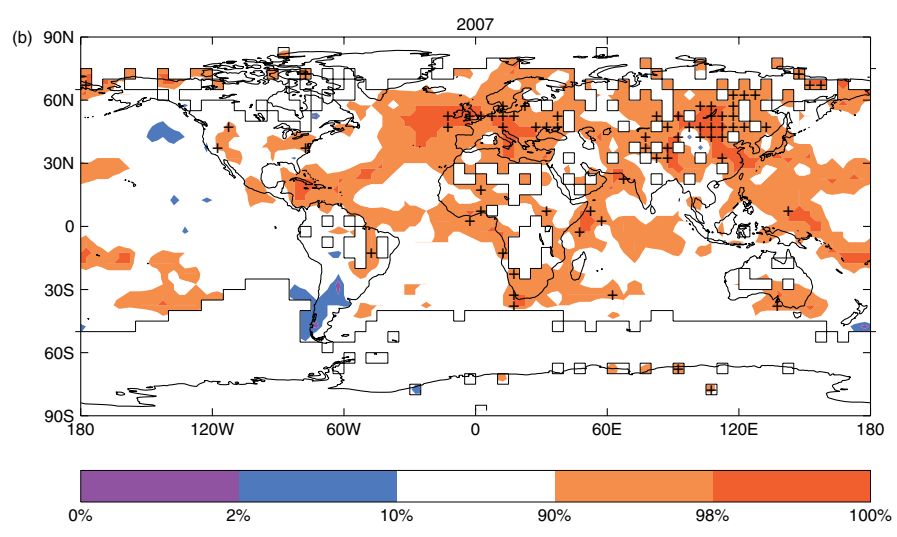

Figure 3(b). As Figure 3(a), but expressed as percentiles of modified 2-parameter gamma distributions fitted to annual data for 1961-1990 processed in the same way as in (a) (Horton et al., 2001). Crosses indicate that 2007 was the warmest year on record in that $5^{\circ}$ latitude $\times 5^{\circ}$ longitude pixel. In some pixels there are too few data in the climatology period to calculate accurate percentile distributions. As a result, there are more missing data points in Figure 3(b) than in Figure 3(a).
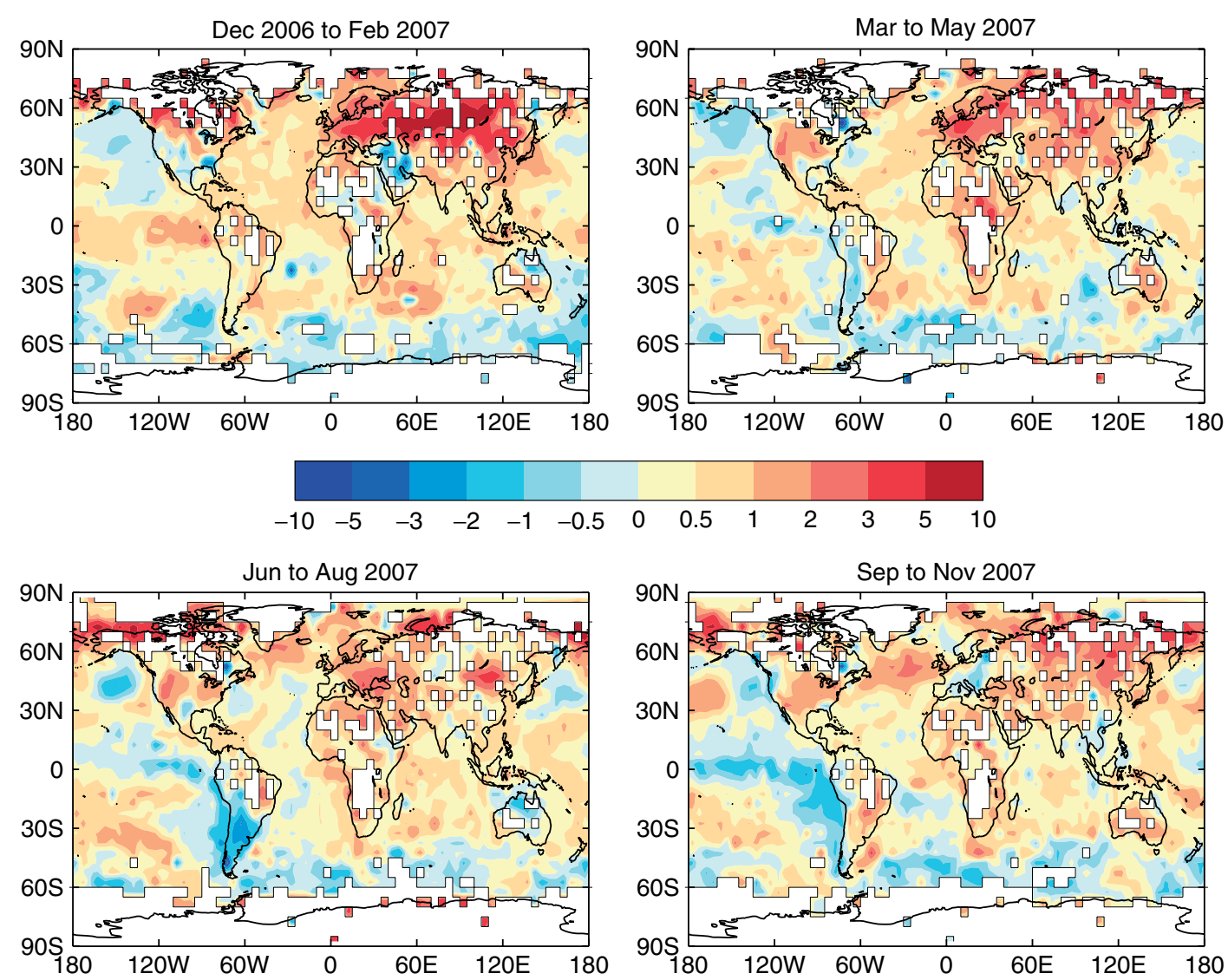

Figure 4(a). Surface temperature anomalies (degC, relative to 1961-1990) for December 2006 to February 2007; March to May 2007; June to August 2007; and September to November 2007. At least one month's data is required for a pixel to be assigned an anomaly. Data are from Brohan et al. (2006).

90th percentile because of the brevity of the temperature record, but the evidence from the reduced ice cover and satellite SST data (see below) is that the temperature anomalies were extreme. Significant cold anomalies - temperatures below the 10th percentile of occurrence - were reported in limited areas in the North Pacific, tropical Pacific and Argentina. Below-average temperatures were recorded over wide areas of the Southern Ocean but their significance is vations in the climatology period to estimate the percentiles.

The $(\mathrm{NH})$ winter was particularly warm over Eurasia (Figures 4(a) and (b)) with significant warm anomalies extending in a band from the UK in the west to northern China in the east. SSTs were much above average across large areas of the North Atlantic, Indian Ocean and western Pacific. Significant cold anomalies were observed only over limited areas of the Middle East.
Large areas of western Europe experienced their warmest spring on record and exceptionally high temperatures were measured in parts of southern Asia, tropical Africa and Australia. Although cool anomalies had started to develop in the tropical Pacific by the end of $(\mathrm{NH})$ spring, the only land area experiencing significant cold was Argentina.

The low temperatures over Argentina persisted into the ( $\mathrm{SH}$ ) winter and temperatures during July and August were below the 2 nd percentile of occurrence. Areas of 

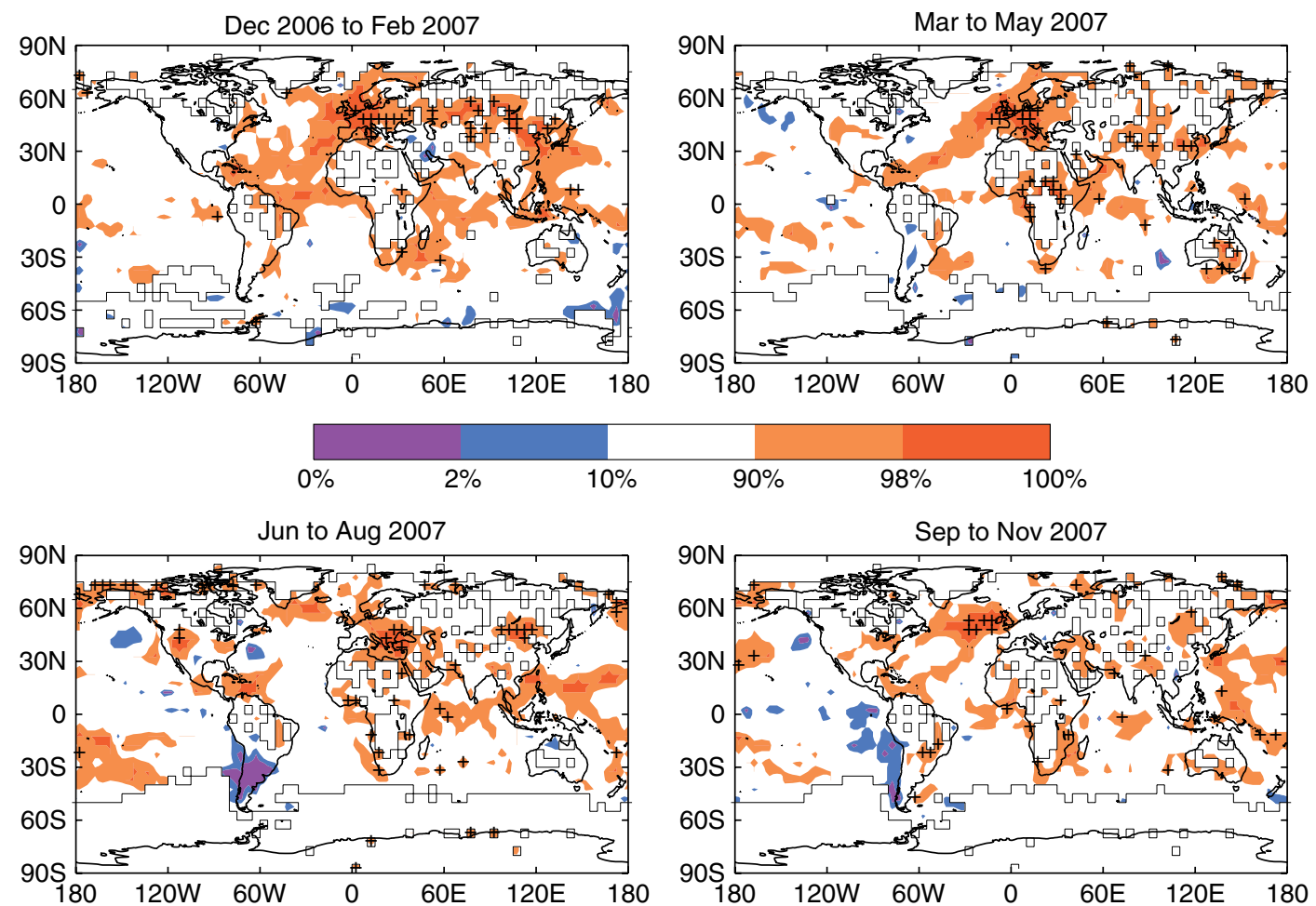

Figure 4(b). As Figure 4(a), but expressed as percentiles of modified 2-parameter gamma distributions fitted to seasonal data for 1961-1990 processed in the same way (Horton et al., 2001). Crosses indicate that 2007 was the warmest season on record in that $5^{\circ}$ latitude $\times 5^{\circ}$ longitude pixel, dashes that 2007 was the coldest.

significantly cold SST formed in the north Pacific and in the western North Atlantic. During the $(\mathrm{NH})$ summer, south-eastern Europe, parts of the USA, Mongolia and China were significantly warmer than average and large areas of the Arctic Ocean north of Alaska were warmer than at any time in the record.

By the start of (NH) autumn, La Niña conditions were well established. Negative SST anomalies spread across the Tropical Pacific and along the whole eastern rim of the basin. Areas experiencing significant warm anomalies were more limited, although most land areas were still warmer than average.

\section{Temperatures in the free atmosphere}

Temperatures aloft are monitored by radiosondes and Microwave Sounding Unit (MSU) satellite retrievals. Figure 5 shows global lower tropospheric and stratospheric MSU-equivalent temperature anomalies from the radiosonde data set HadAT2 (Thorne et al., 2005a), and from MSU datasets produced by the University of Alabama (UAH, version 5.2 for the troposphere and 5.1 for the stratosphere; Christy et al., 2003; Christy and Spencer, 2005) and Remote Sensing Systems (RSS, version 3.0; Mears et al., 2003; Mears and Wentz, 2005). Although interannual variations in the datasets are largely in agreement, differences can be seen in the long-term trends depicted in the right-hand panels. The disagree- ment in the trends at all levels is a result of structural uncertainties that arise from differing dataset development methods (Thorne et al., 2005b; McCarthy et al., 2007). An example of this is that recent radiosonde analyses (Haimberger, 2007; Haimberger et al., 2008; Sherwood et al., 2008; Titchner et al., 2008) may have been more successful than Thorne et al., (2005a) at removing cooling biases in the raw data, particularly in the tropics.

Global annual average temperatures in the lower troposphere in 2007 were the third-, fourth- and ninth-highest in the HadAT2, UAH and RSS series respectively. The recent La Niña is reflected in a cooling in the troposphere as well as at the surface. In the long term, global average warming in the troposphere is proceeding at a similar rate to that recorded at the surface (Figure 5, right-hand panels).

In recent years, controversy has surrounded observations of the tropical troposphere (not shown), because many datasets had shown that it was warming less than the surface during the satellite era. Douglass et al. (2007) recently claimed that a fundamental discrepancy exists between available observational estimates of tropical tropospheric change and climate models, which indicate that in the tropics the temperatures aloft should show an amplification of surface trends owing to latent heat release (Santer et al., 2005, Karl et al., 2006). Santer et al. (2008) revisited the issue and not only found two major statistical errors in the method of Douglass et al., but also considered a much broader range of observational estimates including a number of new radiosonde analyses, some of which were made available to, but not used by Douglass et al. The conclusion reached in Santer et al. (2008) is that there is no meaningful evidence for a difference between modelled and observed behaviour in the tropics.

The global lower stratospheric temperatures in 2007 were the third-, first- and fifth-lowest for the HadAT2, UAH and RSS series respectively. The tropics saw cooling throughout 2007 as a result of the easterly phase of the Quasi-Biennial Oscillation. All long-term stratospheric temperature trends show overall cooling, although there has been little change since the mid-1990s. The radiosonde-based cooling trends are likely to have been exaggerated by uncompensated instrumental changes (Randel and Wu, 2006).

\section{Local and regional climate}

The annual average temperature anomaly over Europe was $+1.24 \pm 0.13 \mathrm{deg} C$ in 2007, which is virtually certainly one of the five warmest years in the series. The Netherlands, Belgium, the Czech Republic, Denmark and several countries in eastern and south-eastern Europe experienced their warmest year on record. 2007 was the second-warmest year in the 94-year record for the UK as a whole $\left(9.59^{\circ} \mathrm{C}\right.$; Perry and Hollis, 2005a and b) and the joint-tenth-warmest in the 349year Central England Temperature series (10.48 $\pm 0.18^{\circ} \mathrm{C}$, CET; Manley, 1974; Parker 

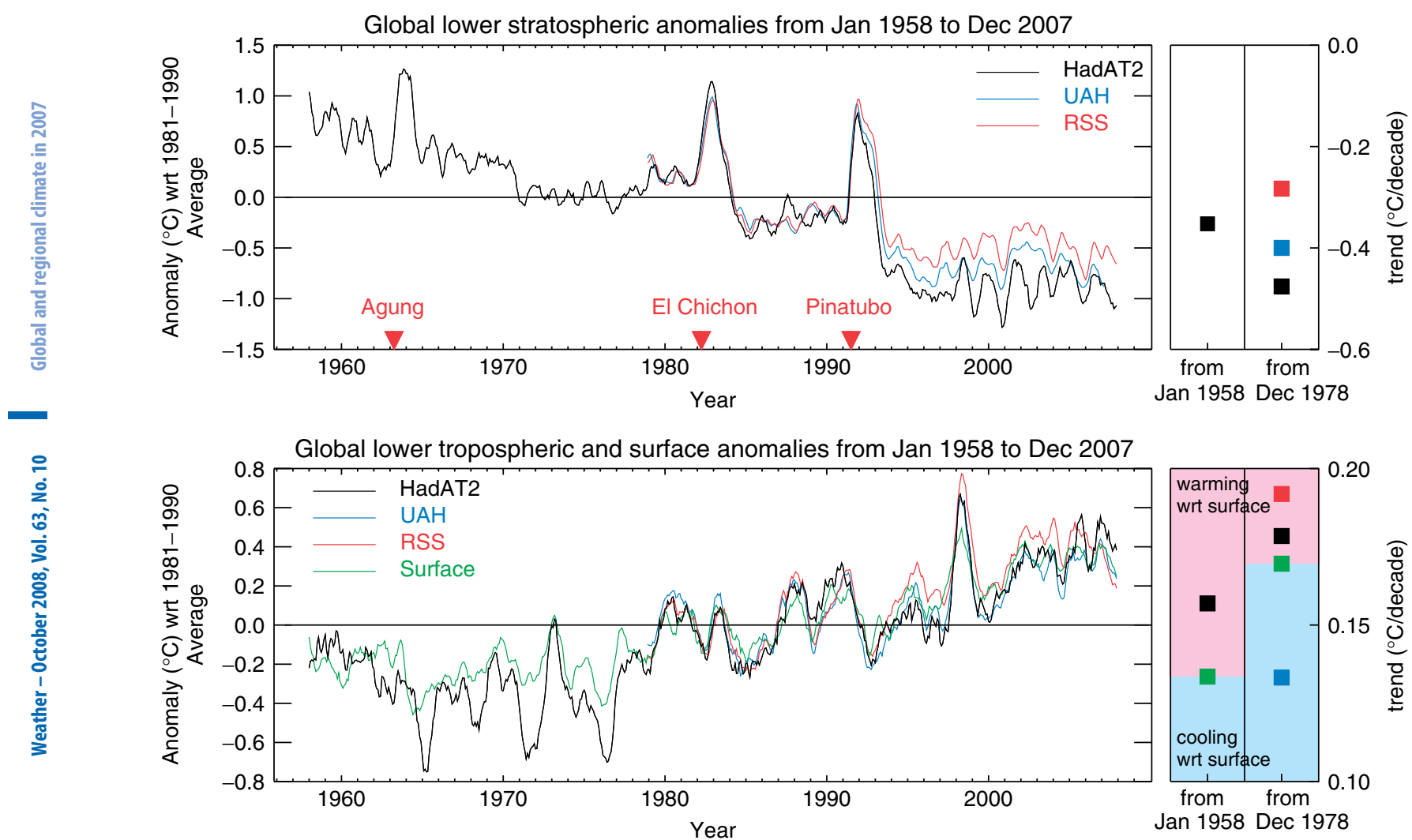

HadAT2 radiosonde data and HadCRUT3 surface data are produced by the Hadley Centre and are available at www.hadobs.org

UAH MSU satellite data are produced by the University of Alabama in Huntsville and are available at www.nsstc.uah.edu/public/msu courtesy of John Christy and Roy Spencer RSS MSU satellite data are produced by Remote Sensing Systems and are available at www.remss.com courtesy of Carl Mears

Figure 5. Global lower stratospheric and lower tropospheric temperature anomalies relative to 1981-1990 from satellites and radiosondes. UAH (University of Alabama, Huntsville, blue) and RSS (Remote Sensing Systems, red) are two independently produced satellite estimates based upon the same Microwave Sounding Unit (MSU) temperature retrievals. HadAT2 (black) has been vertically weighted to create MSU-equivalent time-series from radiosonde data and the surface (green) temperature anomalies are based on HadCRUT3. The monthly series have all been smoothed using a simple 7-point moving filter. The squares on the right hand panels denote the trends for the radiosonde and satellite eras, calculated using a median of pairwise slopes approach. The blue/pink areas on the tropospheric highlight tropospheric cooling/warming relative to the surface. (Thorne et al., 2005a.)
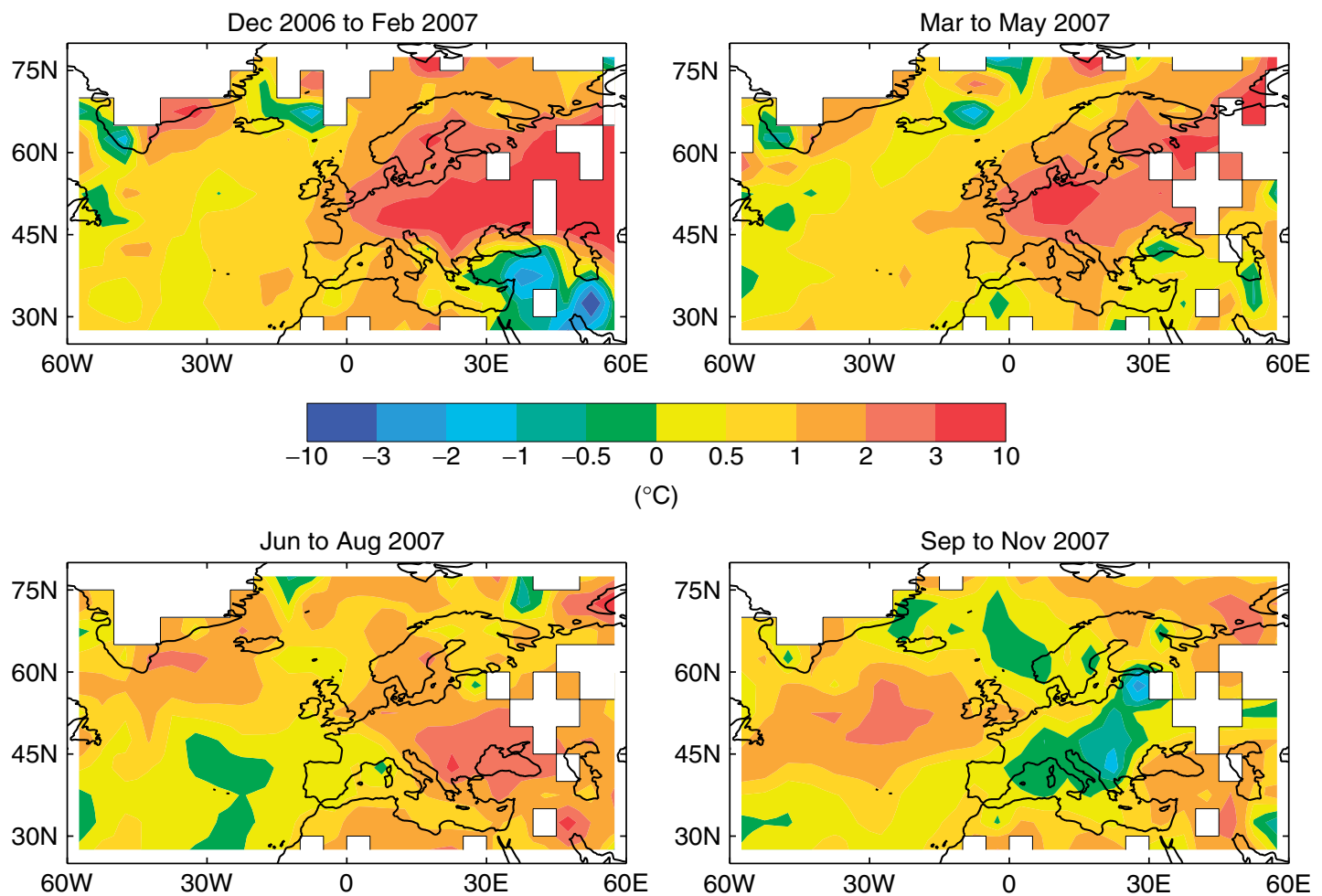

Figure 6(a). Surface air temperature anomalies for Europe and sea-surface temperature anomalies for neighbouring waters (degC, relative to 1961-1990) for December 2006 to February 2007; March to May 2007; June to August 2007; and September to November 2007. At least one month's data are required 

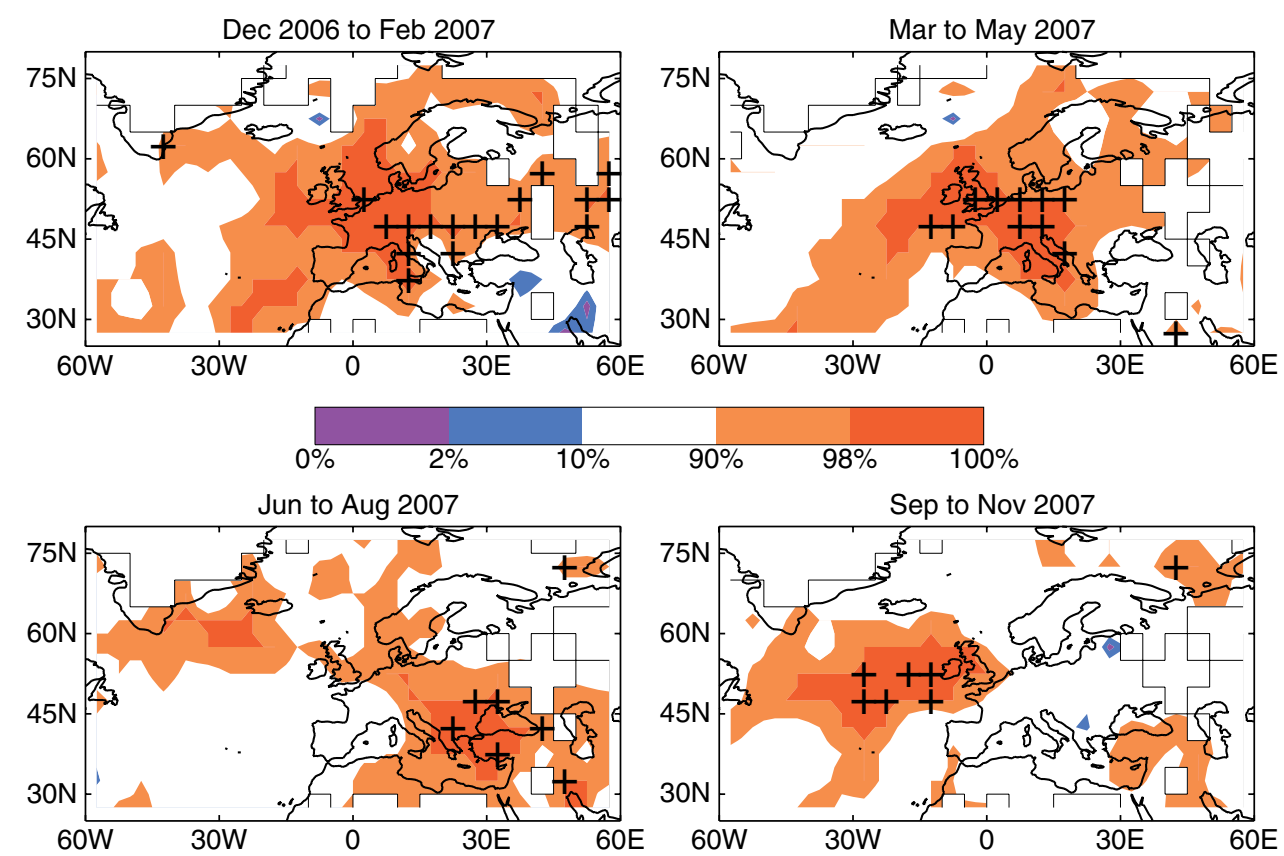

Figure 6(b). As Figure 6(a), but expressed as percentiles of modified 2-parameter gamma distributions fitted to 1961-1990 data (Horton et al., 2001). Crosses indicate that 2007 was the warmest season on record in that $5^{\circ}$ latitude $\times 5^{\circ}$ longitude pixel; dashes indicate that 2007 was the coldest.
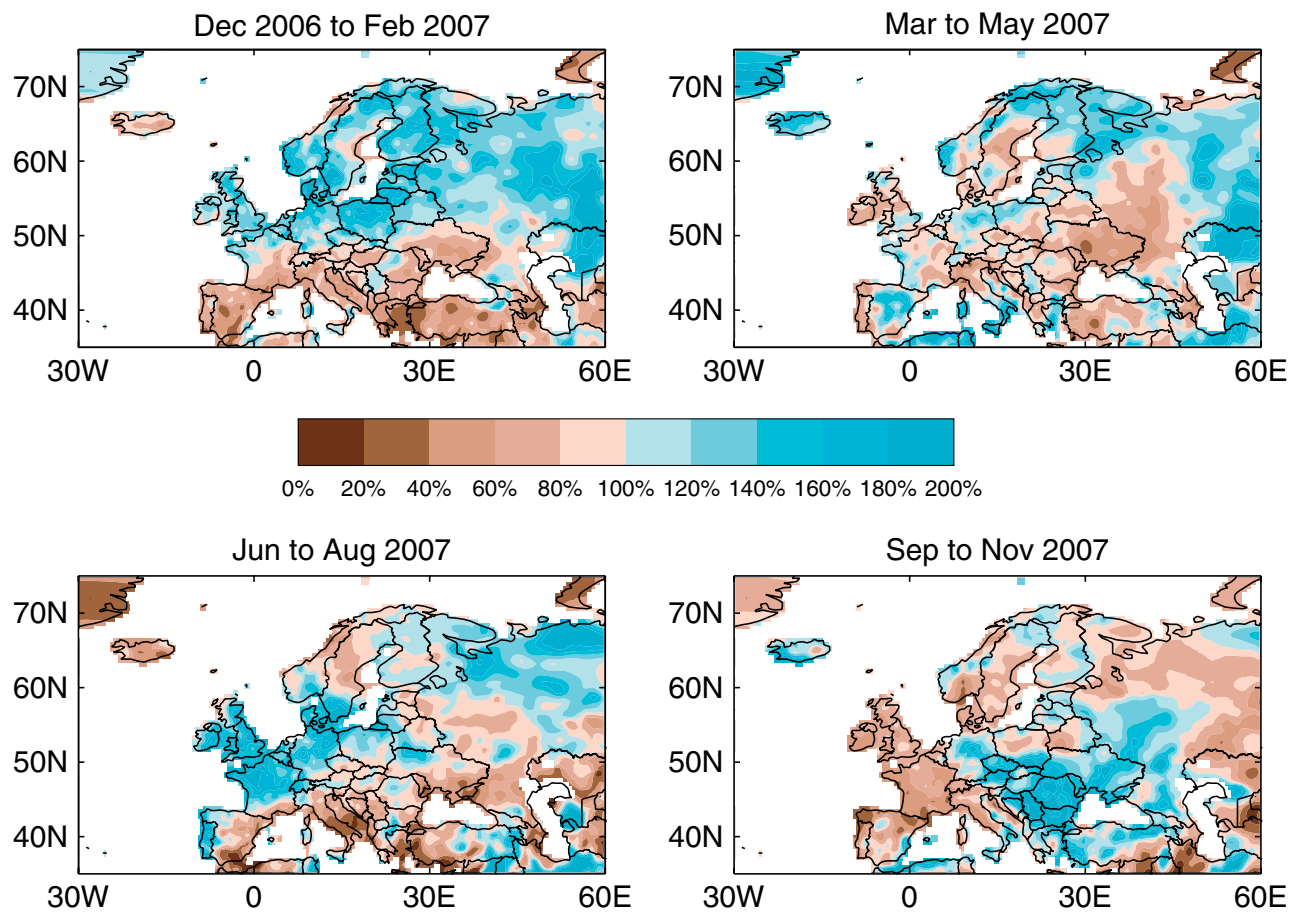

Figure 7. Precipitation anomalies expressed as a percentage of the 1961-1990 average for December 2006 to February 2007; March to May 2007; June to August 2007; and September to November 2007. Data are from the Global Precipitation Climatology Centre (Rudolf et al., 1994; Beck et al., 2005; Rudolf et al., 2005; Rudolf and Rubel, 2005; Rudolf and Schneider, 2005; Fuchs et al., 2007; GPCC.)

et al., 1992; Parker and Horton, 2005; Table 1 and Figure 8).

Winter 2006/2007 was significantly milder than average over much of Europe (Figures $6(a)$ and (b)) with many areas in the south and east reporting record-high winter temperatures. The only area with below-average temperatures was Turkey. Precipitation totals were above average in northern Europe and generally below average in the south (Figure 7), as expected given the stronger-than-usual westerly airflow. On 15 January, extra-tropical storm Kyrill developed over Newfoundland. It reached the UK on the evening of the 17 January. Between the 17 and 20 January the storm moved across Britain, the Netherlands, Germany and Poland, causing 49 deaths and around $\$ 10$ billion of damage (Munich Re, 2008).

The unusual warmth persisted into the spring. Record seasonal average temperatures were reported in Germany, the Netherlands, Switzerland, Belgium and France. April was particularly warm and temperatures exceeding the 98th percentile of occurrence were reported from the UK to Italy. The same areas were also unusually dry with many parts receiving less than $20 \%$ of the average April rainfall. The England and Wales Precipitation (EWP; Alexander and Jones, 2001) index for April was $9.5 \mathrm{~mm}$, making it the fourth-driest April in the record (1766-2007), and the driest April since 1938. East Anglia and south-east England received only around 5\% of the 1961-1990 average precipitation. The unusually dry conditions were accompanied by record-breaking temperatures. In the Central England area, April 2007 was, at $11.2 \pm 0.4^{\circ} \mathrm{C}$ ( $3.3 \mathrm{deg} \mathrm{C}$ warmer than the 1961-1990 average; Table 1 and Figure 9), the warmest recorded April in the CET series. The mean daily maximum 
Table 1

Monthly mean Central England Temperature (CET) (Manley, 1974; Parker and Horton 2005) and England and Wales precipitation (EWP) (Alexander and Jones, 2001), for 1961-1990 and 2007. Monthly values for 2007 have been rounded to the nearest $0.1 \mathrm{deg}$ Cor the nearest millimetre.

\begin{tabular}{|lcccr|}
\hline & CET 1961-90 $\left({ }^{\circ} \mathrm{C}\right)$ & $\begin{array}{c}\mathrm{CET} 2007\left({ }^{\circ} \mathrm{C}\right) \\
(\text { anomaly degC) }\end{array}$ & $\begin{array}{r}\text { EWP 1961-90 } \\
(\mathrm{mm})\end{array}$ & $\begin{array}{r}\text { EWP 2007 }(\mathrm{mm}) \\
\text { (anomaly \%) }\end{array}$ \\
\hline January & 3.81 & $7.0(+3.2)$ & 91 & $99(109)$ \\
February & 3.76 & $5.8(+2.0)$ & 65 & $111(171)$ \\
March & 5.68 & $7.2(+1.5)$ & 74 & $62(84)$ \\
April & 7.89 & $11.2(+3.3)$ & 62 & $10(16)$ \\
May & 11.16 & $11.9(+0.7)$ & 65 & $121(186)$ \\
June & 14.16 & $15.1(+0.9)$ & 65 & $155(238)$ \\
July & 16.05 & $15.2(-0.9)$ & 62 & $139(224)$ \\
August & 15.77 & $15.4(-0.4)$ & 77 & $58(75)$ \\
September & 13.60 & $13.8(+0.2)$ & 78 & $48(62)$ \\
October & 10.62 & $10.9(+0.3)$ & 87 & $52(60)$ \\
November & 6.55 & $7.3(+0.8)$ & 92 & $85(92)$ \\
December & 4.65 & $4.9(+0.3)$ & 96 & $89(93)$ \\
Annual & 9.47 & $10.48(+1.01)$ & 914 & $1028(112)$ \\
\hline
\end{tabular}

temperature for south-east and central southern England was around $5.5 \mathrm{deg} C$ above average. The 12-month period ending 30 April 2007 was the warmest 12-month period in the CET series by a significant margin, averaging $11.6 \pm 0.18^{\circ} \mathrm{C}$, which is $2.1 \mathrm{deg} C$ above the 1961-1990 normal. The previous warmest 12-month period was 1 November 1994 to 31 October 1995, which was $1.6 \pm 0.18 \mathrm{deg} C$ above the 1961-1990 normal. The average spring (MAM) CET for 2007 was the second-highest on record. Conditions became more unsettled in May leading to wetter, cooler conditions particularly in northern and western Europe. May $2007(121 \mathrm{~mm})$ was the tenth-wettest May in the 242-year EWP series.

The summer was characterized by anomalous cyclonic conditions. A series of depres- sions crossed the UK bringing heavy rain that caused extensive flooding in June and July. The period May to July 2007 was the wettest May to July in the EWP series $(415 \mathrm{~mm})$. More detail on the unusually wet weather of summer 2007 can be found in the September 2008 special issue of Weather.

The wet weather affected much of northern Europe including France, Germany and the southern tip of Sweden. In contrast, countries in south-east Europe experienced their warmest summer on record and maximum temperatures exceeding $40^{\circ} \mathrm{C}$ were recorded in a number of areas. On 25 June, Foggia in southern Italy reported a maximum temperature of $47.0^{\circ} \mathrm{C}$.

Temperatures were below average in central areas of Europe during the autumn. The lowest anomalies were observed in the south-east, where it was also wetter than average. Temperatures in the west were close to or above average and Spain, France and the UK were drier than the long-term mean. The CET was slightly above average and the EWP was below average during September, October and November. In the North East England Precipitation Series (NEEP) series, October was the ninth-driest in 135 years, with $26 \mathrm{~mm}$ (average $67 \mathrm{~mm}$ ). December 2007 had generally close to average rainfall and temperatures.

Arctic sea-ice declined rapidly during summer 2007 and reached an unprecedented low in September. This record low is particularly striking when compared to the historical time series since 1955 and the median sea-ice extent (Figure 10). Record minima were also reported for July, August, and October, although such extreme values were not observed earlier in the year. This can be seen in the time series for March (Figure 10), when sea-ice extent typically reaches the annual maximum. Over recent decades sea-ice has significantly decreased in all months, although the sharpest decline has been in September. One likely cause of the 2007 record summer loss is the thinning of pack ice in recent years owing to a transition towards younger ice (Maslanik et al., 2007; Nghiem et al., 2007). In addition, anticyclonic conditions over the central Arctic Ocean along with low pressure over Siberia from June to August resulted in warm southerly winds and clear skies over the Arctic Ocean in the region of the East Siberian and Chukchi Seas where the greatest losses of sea ice were seen and SSTs were at times more than $7 \mathrm{deg} C$ above average. The melting was accelerated by extra absorption of solar heat by the ocean where ice-cover was less than usual; this created even more open water to absorb solar heat, further accelerating the melting in an 'ice-albedo
Central England Mean Temperature

Annual anomalies, 1878 to 2007 relative to $1961-1990$ with $+/-2$ standard error bars

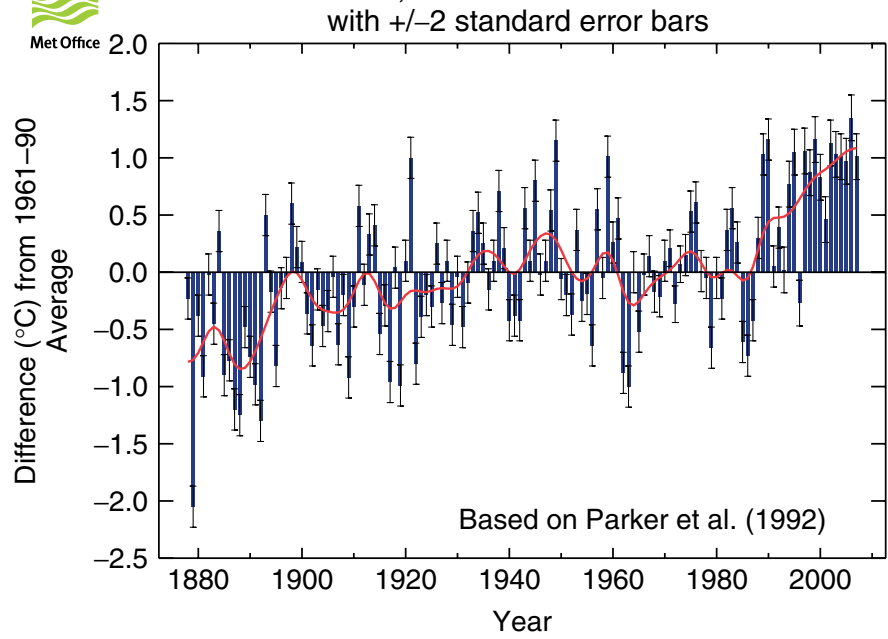

Figure 8. Annual mean Central England Temperature anomalies relative to 1961-1990. The blue bars indicate the annual values. The uncertainty range represents \pm 2 standard errors. The smooth curve was created using a 21-point binomial filter to highlight the interdecadal variations

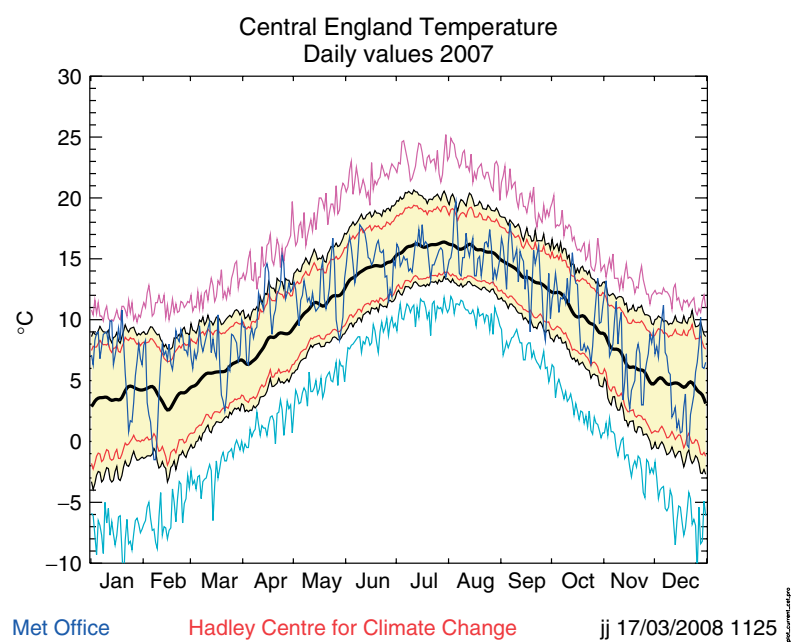

Figure 9. Daily mean Central England Temperature $\left({ }^{\circ} \mathrm{C}\right.$ ) for 2007 (dark blue line). The heavy black line shows the normal for 1961-1990, after 11-term binomial smoothing, and the red lines are the corresponding 10th and 90th percentiles for each day of the year. The yellow band is the interval between the 5th and 95th percentiles. The magenta and cyan lines represent the highest and lowest values of daily mean CET in the entire record since 1772 (Parker et al., 1992). 

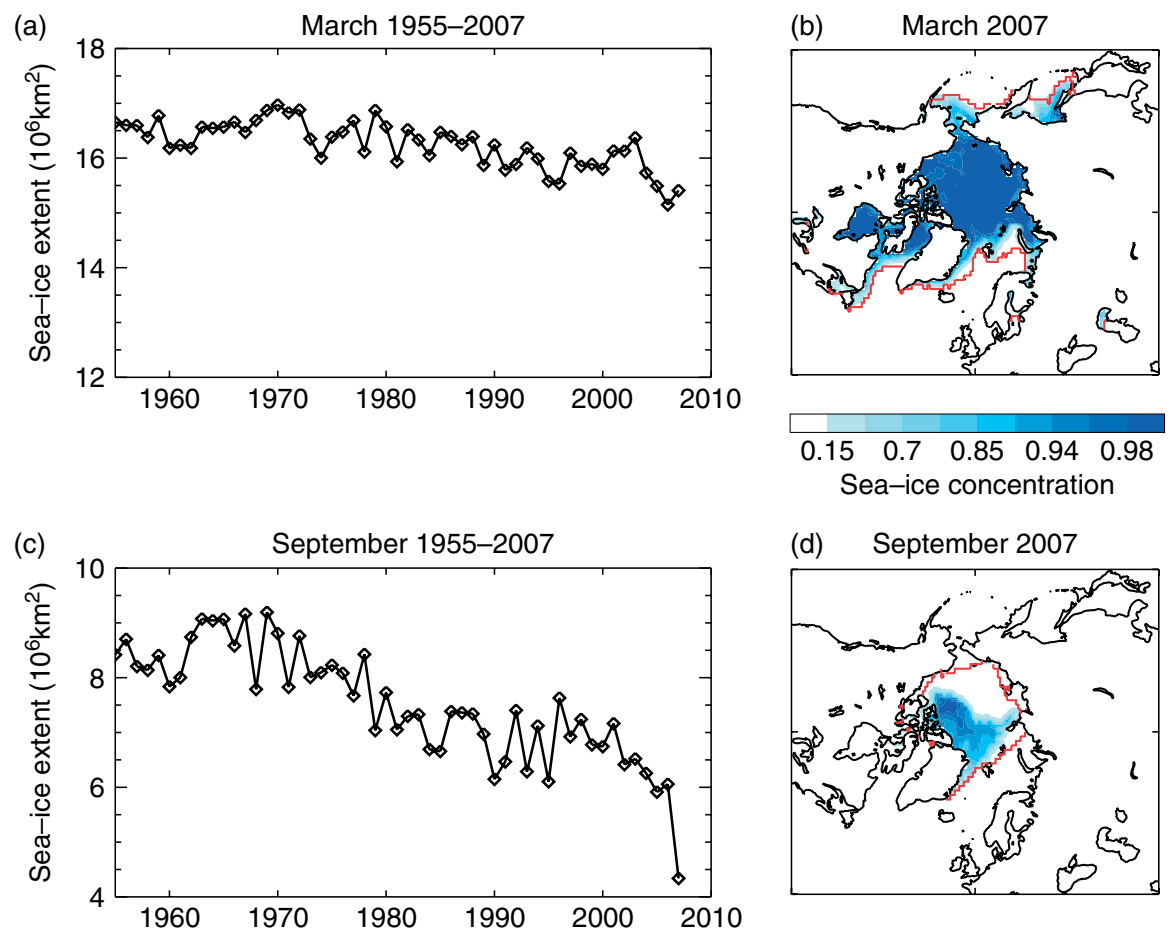

$\begin{array}{lllll}0.15 & 0.7 & 0.85 & 0.94 & 0.98\end{array}$

(d) September 2007

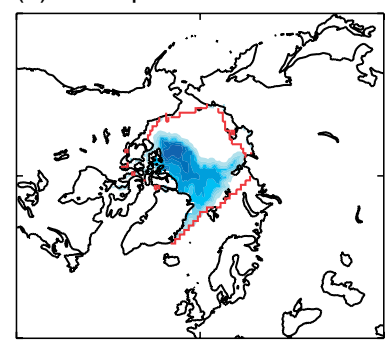

Figure 10. Arctic sea-ice extent $\left(10^{6} \mathrm{~km}^{2}\right)$ for March (top left) and September (bottom left) from 1955 to 2007. The right hand panels show sea-ice concentration (blue shading) for March 2007 (top) and September 2007 (bottom) and the median ice extent for each month (red line). The analysis, updated from Rayner et al. (2003) is mainly based on retrievals from microwave sensors on polar-orbiting satellites as described in the text. Sea-ice extent is obtained by summing the area covered by all $1 \%$ latitude by $1 \%$ ongitude elements which have $15 \%$ or greater sea-ice concentration.

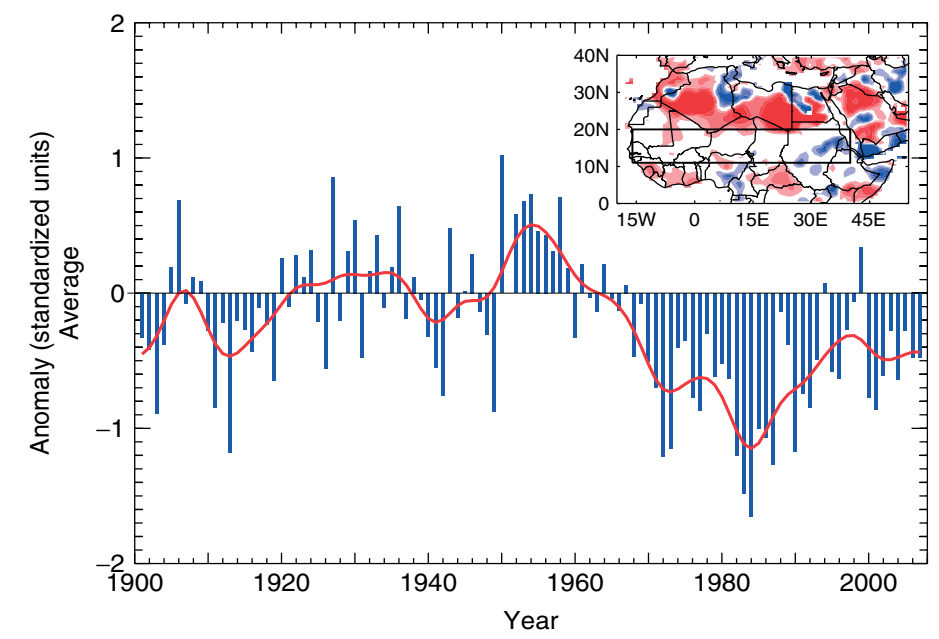

Figure 11. Annual rainfall anomalies (in standardized units) for the Sahel during 1901-2007.

Standardization is based on averages and standard deviations of stations' data for generally around 50 years ending 1973 (Nicholson, 1985). The smooth curve was created by applying a 21-term binomial filter to the annual values. The values from 1901-1984 are from Nicholson (1985). From 1985-2000 the values are calculated from Met Office climate data. The values for 2001 onwards are based on the NCEP gridded gauge data (Chen et al., 2002). The inset shows percentage precipitation anomalies relative to the 1961-1990 long-term average for North Africa for January to December 2007 taken from the Global Precipitation Climatology Centre (GPCC) precipitation dataset. The boxed region indicates the approximate extent of the Sahel region. Red areas were drier than the long-term average, blue areas were wetter.

feedback' process (Perovich et al., 2008). The Northwest Passage was navigable at the end of summer 2007, but sea-ice extent to the east of Greenland was near normal. As the winter growth commenced, the extent began to return to more typical values. November and December were about the same as in 2006, but the ice pack will include a smaller fraction of thick multiyear ice and

a larger fraction of thinner first-year ice. The ice is therefore likely to be more susceptible to melting in summer 2008. In the Southern Hemisphere, around Antarctica, the 2007 sea-ice extent was close to average.

In the north African Sahel, on the southern fringes of the Sahara, 2007 had a similar total rainfall to 2006 (Figure 11). The smoothed curve shows the decadal evolu- tion of the rainfall and indicates that the past decade, although somewhat drier than the long-term average, has still been moister than the severe drought of the early 1970's and mid-1980's. The Sahel rainfall series is not representative of semi-arid areas of North Africa, such as mountainous, sparsely observed Ethiopia (Conway et al., 2004), but Dai et al., (2004) have confirmed the overall reliability of the long-term variations in the series. Although 2007 was drier than the long-term average, heavy rainfall during the rainy season (July-October) led to widespread flooding from Nigeria to Ethiopia. Hundreds of people died and more than half a million were left homeless.

More detail on the climate of 2007 is to be found in the World Meteorological Organization's (WMO) statement on the status of global climate in 2007 on www. wmo.int and in the NCEP Climate Prediction Centre's State of the Climate 2007 report in the July issue of the Bulletin of the American Meteorological Society. A fuller account of European climate will be published by WMO in its Annual Bulletin on the Climate in WMO Region VI - Europe and the Middle East, 2007. Selected global and UK datasets can be accessed from www.metoffice.gov.uk/ hadobs. A wider background for our results can be found in IPCC (2007), in particular Chapter 3, available from www.ipcc.ch

\section{Acknowledgements}

The authors were supported by the Joint Defra and MoD Programme, (Defra) GA01101 (MoD) CBC/2B/0417_Annex C5. They would like to thank Andrew Colman, who provided Sahel data and Prof. Phil Jones at the University of East Anglia who contributed to the land-surface air temperature analysis. UAH MSU data are produced by the University of Alabama Huntsville and are available at www.nsstc.uah.edu/public/msu courtesy of John Christy and Roy Spencer. RSS MSU satellite data are produced by Remote Sensing Systems and are available at www.remss.com courtesy of Carl Mears. Tobias Fuchs provided high-resolution precipitation data for Europe.

\section{References}

Alexander LV, Jones PD. 2001. Updated precipitation series for the U.K. and discussion of recent extremes. Atmos. Sci. Lett. 1: DOI:10.1006/asle.2001.0025.

Beck C, Grieser J, Rudolf B. 2005. A new monthly precipitation climatology for the global land areas for the period 1951 to 2000. DWD, Klimastatusbericht KSB 2004, ISSN 1437-7691, ISSN 1616-5063 (Internet), ISBN 3-88148-402-7, 181-190. Brohan P, Kennedy JJ, Harris I, Tett SFB, Jones PD. 2006. Uncertainty estimates in regional and global observed temperature changes: a new dataset from 1850. J. Geophys. Res. 111: D12106, DOI:10.1029/ 2005JD006548. 
Chen M, Xie P, Janowiak JE, Arkin PA. 2002. Global land precipitation: A 50-yr monthly analysis based on gauge observations. J. Hydrometeorol. 3: 249-266. Christy JR, Spencer RW. 2005. Correcting temperature data sets. Science 310: 972.

Christy JR, Spencer RW, Norris WB, Braswell WD, Parker DE. 2003. Error estimates of version 5.0 of MSU-AMSU bulk atmospheric temperatures. J. Atmos. Oceanic Technol. 20: 613-629.

Conway D, Mould C, Bewket W. 2004 Over one century of rainfall and temperature observations in Addis Ababa, Ethiopia. Int. J. Climatol. 24: 77-91.

Dai A, Lamb PJ, Trenberth KE, Hulme M, Jones PD, Xie P. 2004. The recent Sahel drought is real. Int. J. Climatol. 24: 1323-1331.

Douglass DH, Christy JR, Pearson BD, Singer SF. 2007. A comparison of tropical temperature trends with model predic tions. Int. J. Climatol. 27: DOI:10.1002/ joc. 1651.

Fuchs T, Schneider U, Rudolf B. 2007.

Global precipitation analysis products of the GPCC. Global Precipitation Climatology Centre (GPCC), DWD, Internet publication, 1-10.

GPCC Homepage: http://gpcc.dwd.de (1994-2007).

Haimberger L. 2007. Homogenization of radiosonde temperature time series using innovation statistics. J. Climate 20: 1377-1403.

Haimberger L, Tavolato C, Sperka S. 2008. Towards elimination of the warm bias in historic radiosonde records - some new results from a comprehensive intercomparison of upper air data. J. Climate (in press).

Horton EB, Folland CK, Parker DE. 2001. The changing incidence of extremes in worldwide and central England temperatures to the end of the twentieth century. Clim. Change 50: 267-295.

IPCC. 2007. Climate Change 2007: The Physical Science Basis. WG1 Summary for Policymakers. Cambridge University Press: Cambridge, UK; 18pp.

Karl TR, Hassol SJ, Miller CD, Murray WL (eds). 2006. Temperature trends in the lower atmosphere: Steps for understanding and reconciling differences. A report by the Climate Change Science Program and the Subcommittee on Global Change Research: Washington, DC.

Knight JR, Allan RJ, Folland CK, Vellinga M, Mann ME. 2005. A signature of persistent natural thermohaline circulation cycles in observed climate. Geophys. Res. Lett. 32: L20708, DOI:10.1029/ $1005 G L 024233$.

Knight JR, Folland CK, Scaife AA. 2006. Climate impacts of the Atlantic Multidecadal Oscillation, Geophys. Res. Lett. 33: L17706, DOI:10.1029/ 2006 GL026242.

Manley G. 1974. Central England temperatures: monthly means 1659 to 1973. Q. J. R. Meteorol. Soc. 100: 389-405.

Maslanik JA, Fowler C, Stroeve J, Drobot S, Zwally J, Yi D, Emery W. 2007. A younger, thinner Arctic ice cover: Increased potential for rapid, extensive sea-ice loss. Geophys. Res. Lett. 34: L24501, DOI: 10.1029/2007GL032043.

Mears CA, Schabel MC, Wentz FJ. 2003. A reanalysis of the MSU Channel 2 tropospheric temperature record. J. Climate 16: 3650-3664.

Mears CA, Wentz FJ. 2005. The effect of diurnal correction on satellite-derived lower tropospheric temperature. Science 309: 1548-1551.

McCarthy MP, Titchner HA, Thorne PW, Tett SFB, Haimberger L, Parker DE. 2007. Assessing bias and uncertainty in the HadAT adjusted radiosonde climate record. J. Climate 21: 817-832.

Munich Re NatCatSERVICE. 2008. The ten largest natural catastrophes in 2007. http://www.munichre.com

Nghiem SV, Rigor IG., Perovich DK, Clemente-Colon P, Weatherly JW, Neumann G. 2007. Rapid reduction of Arctic perennial sea ice. Geophys. Res. Lett. 34: L19504, DOI:10.1029/2007GL031138.

Nicholson SE. 1985. Sub-Saharan rainfall 1901-1984. J. Clim. Appl. Meteorol. 24: 1388-1391.

Parker DE, Legg TP, Folland CK. 1992.

A new daily Central England temperature series, 1772-1991. Int. J. Climatol. 12: 317-342.

\section{Parker DE, Horton EB. 2005.}

Uncertainties in central England temperature 1878-2003 and some improvements to the maximum and minimum series. Int. J. Climatol. 25: 1173-1188.

Perovich DK, Richter-Menge JA, Jones KF, Light B. 2008. Sunlight, water, and ice: Extreme Arctic sea-ice melt during the summer of 2007, Geophys. Res. Lett., 35 L11501, DOI:10.1029/2008GL034007.

Perry MC, Hollis DM. 2005a. The development of a new set of long-term average climate averages for the UK. Int. J. Climatol. 25: 1023-1039.

Perry MC, Hollis DM. 2005b. The generation of monthly gridded datasets for a range of climatic variables over the UK Int. J. Climatol. 25: 1041-1054.

Randel WJ, Wu F. 2006. Biases in stratospheric temperature trends derived from historical radiosonde data. J. Climate 12: 2094-2104.

Rayner NA, Brohan P, Parker DE, Folland CK, Kennedy JJ,Vanicek M, Ansell T, Tett SFB. 2006. Improved analyses of changes and uncertainties in sea surface temperature measured in situ since the mid-nineteenth century: the HadSST2 data set. J. Climate 19: 446-469.

Rayner NA, Parker DE, Horton EB, Folland CK, Alexander LV, Rowell DP, Kent EC, Kaplan A. 2003. Global analyses of sea surface temperature, sea-ice and night marine air temperature since the late nineteenth century. J. Geophys. Res. (Atmospheres) 108(D14): 4407, DOI:10.1029/2002JD002670.

Rudolf B, Hauschild H, Rueth W, Schneider U. 1994. Terrestrial Precipitation Analysis: Operational method and required density of point measurements, in Global Precipitations and Climate Change. Desbois M, Desalmond F (eds). NATO ASI Series I, Vol. 26, SpringerVerlag, Heidelberg; pp 173-186.
Rudolf B, Rubel F. 2005. Global precipitation, in Observed Global Climate. New Series on Landolt-Börnstein, Numerical Data and Functional Relationship. Hantel M (ed.) Springer: Berlin; 11.1-11.53, extended online version (11.1-11.24, print version), ISBN 3-540-20206-4.

Rudolf B, Beck C, Grieser J,

Schneider U. 2005. Global precipitation analysis products. Global Precipitation Climatology Centre (GPCC), DWD, Internet publication, 1-8.

Rudolf B, Schneider U. 2005. Calculation of gridded precipitation data for the global land-surface using in-situ gauge observations, Proceedings of the 2nd Workshop of the International Precipitation Working Group IPWG, Monterey, USA, October 2004, EUMETSAT, ISBN 92-9110-070-6, ISSN 1727-432X 231-247.

Santer BD, Wigley TML, Mears C, Wentz FJ, Klein SA, Seidel DJ, Taylor KE, Thorne PW, Wehner MF, Gleckler PJ, Boyle JS, Collins WD, Dixon KW, Doutriaux C, Free M, Fu Q, Hansen JE, Jones GS, Ruedy R, Karl TR, Lanzante JR, Meehl GA, Ramaswamy V, Russell G, Schmidt GA. 2005. Amplification of surface temperature trends and variability in the tropical atmosphere. Science 309(5740): 1551-1556.

Santer BD, Thorne PW, Haimberger L, Taylor KE, Wigley TML, Lanzante JR, Solomon S, Free M, Gleckler PJ, Jones PD, Karl TR, Klein SA, Mears C, Nychka D, Schmidt GA, Sherwood SC, Wentz FJ. 2008. Consistency of modelled and observed temperature trends in the tropical troposphere. Int. J. Climatol. (in press). DOI: 10.1002/joc.1756

Sherwood SC, Meyer CL, Allen RJ Titchner HA. 2008. Robust tropospheric warming revealed by iteratively homogenized radiosonde data. J. Climate (in press).

Thorne PW, Parker DE, Tett S, Jones P, McCarthy M, Coleman H, Brohan P. 2005a. Revisiting radiosonde upper-air temperatures from 1958 to 2002.

J. Geophys. Res. 110: D18105; DOI:10.1029/ 2004JD005753.

Thorne PW, Parker DE, Christy JR, Mears CA. 2005b. Uncertainties in climate trends: lessons from upper-air temperature records. B. Am. Meteorol. Soc. 86 1437-1442.

Titchner HA, Thorne PW, McCarthy MP, Tett SFB, Haimberger L, Parker DE. 2008. Critically reassessing tropospheric temperature trends from radiosondes using realistic validation experiments. J. Climate (in press).

WMO. 2008. Annual bulletin on the climate in WMO region VI-Europe and the MiddleEast, 2007. (in press).

Correspondence to: John Kennedy Met Office, Hadley Centre, FitzRoy Road, Exeter, EX1 3PB, UK

Email:john.kennedy@metoffice.gov.uk

(c) Crown Copyright, 2008, published with the permission of the Controller of HMSO and the Queen's Printer for Scotland.

DOI: $10.1002 /$ wea.320 